\title{
The Effects of Localization on Economic Performance: Analysis of Spanish Tourism Clusters
}

\author{
Maria-del-Val Segarra-Oña, Universitat Politècnica de València \\ Lluís Gaspar Miret-Pastor, Universitat Politècnica de València, \\ Angel Peiro-Signes, Universitat Politècnica de València \\ Rohit Verma, Cornell University
}

\begin{abstract}
The sun, sea and sand model that has characterized the Spanish tourism sector and has caused Spain's tourist sector to become a world-class industry is actually undergoing drastic changes. This model is based on the existence of major tourism destinations characterized by high levels of industry specialization, which makes them a target of analysis as tourism clusters in which the geographic concentration of synergies reinforces the competitive position. In this study, Spanish tourism clusters are identified using quantitative methods and the current validity of the economies of location that have made them possible are also analyzed. Although all the identified clusters can be defined as mature and became less significant during the last decade in Spanish tourism, according to the results the creation of externalities measured in terms of higher generation of profit is higher in companies belonging to the tourism clusters than in those outside of them.
\end{abstract}

\section{Introduction}

Spain had over 52.2 million tourists in 2009 (UNWTO, 2010) and ranked number three worldwide in the arrival of foreign tourists. Much of the success of Spanish tourism is due to so-called mass tourism destinations (Valenzuela, 1991; Claver et al., 2007; Segreto et al., 2009). These destinations arose in the second half of the twentieth century and quickly became worldwide references for sun, sea and sand tourism (Aguiló et al., 2005). However, the tourism sector in general is facing important changes (Kumral \& Onder, 2009; Papatheodorou et al., 2010) which are particularly significant in the traditional tourism model (Poon, 1993). According to the tourist destination life cycle theory (Butler, 1980), these locations are mature and paradigmatic destinations of so-called second- 
generation tourism under the classification of Knowles and Curtis (1999). Destinations of this type offer a much standardized product controlled by large tour operators which certain authors have identified with Fordist production (Ioannides \& Debbage, 1997). Second-generation tourism tends to be regarded as unsustainable and on the decline (Agarwal, 2002), being unable to adapt to the demands of new more independent, flexible and discerning customers resulting from the emergence of new technologies and lifestyles, which lead to a new tourism model called third generation or neo- Fordism and characterized by higher control and planning, a greater focus on the quality of the tourism product and a decrease in intermediaries (Fayos, 1996).

In this connection, traditional tourist destinations have made significant efforts to reposition themselves and diversify (Aguiló et al., 2005; Avraham \& Ketter, 2008; Polo \& Valle, 2008). In recent years, different studies have been performed analyzing this repositioning in destinations such Costa Blanca (Claver et al., 2007), the Balearic Islands (Aguiló et al., 2005; Alegre \& Caldera, 2006) and the Canary Islands (Sherrer et al., 2009). These analyses stress that this strategy involves both a promotional effort (Hayden, 2009) and an increase in the quality of tourism products offered. Tourist satisfaction is becoming less dependent on traditional factors such as fair weather or the quality of beaches (Alegre \& Garau, 2011) because tourists are increasingly more sophisticated customers who place greater emphasis on factors such as environmental quality and care (Moutinho, 2000; Esteban et al., 2009) as well as local factors and social and economic changes (Pulina \& Biagi, 2010).

Therefore, knowing whether placing hotel and catering establishments in mature destinations continues to offer a competitive advantage (Marrero \& Santana, 2008) is key. Certain authors claim that nowadays mass tourism should be analyzed as a "mature destination" where it is not on the decline (Farsari et al., 2007), although the current economies of agglomeration may offer an advantage to hotel and catering companies located in these territories, as argued, inter alia, by Chun and Kalnins (2001). In this connection, the general aim of this study is to analyze whether Spanish mass tourism destinations form tourism clusters generating externalities which can be measured in terms of the business profits earned by the hotel establishments located therein. The territories which can be considered to be tourism clusters in Spain due to their level of tourism specialization were first identified, following which different economic and financial ratios were compared in hotel establishments located inside and outside the clusters.

To achieve these aims, this study is divided into five sections. First, the aims are presented, and secondly, the concept of tourism cluster is analyzed; in the third section, the Spanish tourism clusters are located, and in the fourth section, the validity of economies of agglomeration is studied by means of 
a comparative analysis between the results of hotel and catering companies inside and outside of the clusters. Lastly, main conclusions are drawn and future lines of research are proposed.

\section{Tourism Cluster and Territory Effect}

The concept of cluster has mainly been used in the manufacturing industry, whereas few studies have been performed on service clusters. This is due to the fact that the existence of a cluster has traditionally been substantiated by "resource" and "supply" externalities and only recently has the concept of "demand" externalities been used (Canina et al., 2005). This new perspective has opened up the possibility of studying clusters in service sectors such as financial (Cook et al., 2007), tourism (Michael, 2003; Jackson \& Murphy, 2006) and other service sectors (Pandit et al., 2008).

Capone and Boix (2008) suggest that high levels of agglomeration in tourism are not based simply on the existence of natural features or an attractive heritage, but rather on the presence of economies of location present on all links of the chain of economic activities relating to tourism products.

Within the scope of industrial districts, there are also studies attempting to relate externalities and the tourism industry (Pearce, 1995; Hjalager, 2000). However, the industrial districts studies focus their analysis on more uniform sectors, and it is difficult to apply them in service sectors where significant inter-industrial relationships are generated (Segarra-Oña \& De Miguel-Molina, 2009).

Studies on tourism clusters have focused mainly on the role played by territory, different actors and productive and social relations (Van den Berg et al., 2001; Nordin, 2003; Hall, 2005; Flowers \& Easterling, 2006), but, from our standpoint, it is necessary to point out two peculiarities.

1. Tourism clusters are the result of the location of complementary companies which do not necessarily belong to the same sector (Novelli et al., 2006), but which benefit from the existence of networks, alliances and other dynamics between them (Tinsley \& Lynch, 2001; Saxena, 2005; Presenza \& Cipollina, 2010; Weidenfeld et al., 2010). This feature allows the concept of "diagonal cluster" to be introduced (Michael, 2003) since the location of new business directly or indirectly related to tourism not only adds value to the companies inside the same cluster but also the tourism experience itself. In these diagonal clusters, trust, relationships and share capital play a key role (Inkpen \& Tsang, 2005).

2. The prominence of cooperation over competition. The traditional microeconomic model of competition is not applicable because in this case companies are required to cooperate to promote a destination (Jackson \& Murphy, 2006). In the tourism market, the first thing sold 
to the customer is the destination. Therefore, services and products must be combined to offer the specific experience sought by the customer (Michael, 2003).

These two peculiarities differentiate the traditional cluster from the tourism cluster. Currently, much of the competitive ability and the ability to react of these mass tourism destinations is a result of the agglomeration of companies and institutions relating to tourism, which are able to create specialized products or services and provide skilled and trained labor, as well as infrastructures and services adapted to needs, thereby generating externalities and acting in a symergetic manner (Segarra et al., 2011). A tourism destination's ability to adapt will depend on the creativity and interaction of the different local bodies (Richards \&Wilson, 2006) on the geographic externalities produced (Lazzeretti \& Capone, 2006) and, ultimately, on the existence of tourism clusters enabling areas to compete globally while working together locally (Novelli et al., 2006; Mazanec et al., 2007; Erkus-Öztürk, 2009; Ferreira \& Estevao, 2009).

However, there is still a certain agreement that the application of the concept of clusters to tourism is appropriate (Jackson \&Murphy, 2002). In any case, the discussion of tourism clusters is still in an early stage (Nordin, 2003). There are recent studies analyzing tourism clusters in specific sectors such as convention tourism (Bernini, 2009) and food and wine tourism (Hall, 2005), as well as the appearance of tourism clusters in transition economies (Jackson \& Murphy, 2006) or emerging economies (Sharma et al., 2007; Erkus, 2009). However, the analysis of mature tourist destinations as tourism clusters should still be studied, as well as the influence of tourism clusters on economic performance.

In the Spanish case, the analysis of touristic clusters is also a recent field of study. There is a perception that a destination's competitive advantage depends on the dynamic level of its agencies, as well as on the coordination of different actors and administrations (Aguiló et al., 2005). In this line, we can find, at the Spanish level, several studies analysing knowledge transmission within tourism clusters (Alvarez \& Gonzalez, 2008), the dynamics of the relationships between public and private levels (Merinero, 2008) or the role that tourism clusters play when innovating and improving their competitiveness (Alvarez \& Gonzalez, 2006; Prats et al., 2008), but there has not been found any study that quantifies the benefits of the cluster effect.

Regarding tourism cluster mapping, it is remarkable in the work of Aurioles et al. (2008) that develops a Spanish map of tourist municipalities classified by type of prevailing tourism. Touristic clusters have also been studied at a regional level; Blasco et al. (2009) mapped Catalunya and Segarra et al. (2011) did it with the Valencian region, but we have not found any study that analyses the economic 
impact of geographic concentration in the tourism sector regardless of administrative boundaries as a measure and considering the area expertise.

In this study, tourism clusters are statistically located in order to analyze their influence on economic performance, which is known as the validation of the district effect in the literature (Soler, 2006; Puig et al., 2008).

In any case, unlike the studies on industrial districts, when studying tourism, it becomes necessary not to restrict the sources of location advantages to the Marshallian concept of externality, but it is necessary to extend it to the Weberian concept of "natural resources" (Weber, 1909; Ellison \& Glaeser, 1997), to the existence of urbanization economies (Jacobs, 1969; Henderson et al., 2001) or to the idea of clusters of demand (Canina et al., 2005).

Signorini (1994) was the first author to attempt to quantify the district effect, showing that the productivity of companies within the district is greater than that of companies outside it. Subsequently, other studies have made similar comparisons focusing on different aspects such as technical efficiency (Hernández \& Soler, 2003), the ability to export (Melitz, 2003), the generation of externalities (MiretPastor \& Segarra, 2010) and the ability to innovate (Canielli \& De Liso, 2004).

In any case, it should be noted that all the literature presented has focused its analysis on industrial sectors. Our study follows the line of research of Fabiani (2000) and focuses on the analysis of financial results, but unlike in all previous studies, an agglomeration of service companies, such as a tourism cluster, and in particular, the economic performance of its hotels is analyzed.

\section{Location of Tourism Clusters: Methodology and Analysis}

In order to identify tourism clusters, a hotel and catering specialization rate was calculated according to the theory of geographic agglomeration and specialization intrinsic to all clusters (O'Donoghue \& Gleave, 2001). The same methodology had previously been used to analyze the performances of clusters in the region of Valencia (Miret-Pastor et al., 2010; Segarra et al., 2011). The data used in the analysis were taken from the population census database (last version available 2001).

The rate used to measure the specialization levels was the location quotient (LQ) $\mathrm{LQ}=E_{\mathrm{is}} / E_{\mathrm{s}} / / E_{i} / E$,

where $E_{i s}$ is the number of employees in province $S$ in sector $i, E_{s}$ is the number of employees in province $S, E_{i s}$ is the number of employees in Spain in sector $i$ and $E$ is the total number of employees in Spain. 
This same LQ method is used for the different cluster mappings (Porter, 1998), and for the location of "local production systems" specializing in tourism (Lazzeretti \& Capone, 2006). Just like the concept of a cluster, this LQ method is simple and flexible, although given its simplicity it is not free from criticism. In recent years, new methods have appeared such as those based on the comparison of spatial distributions (Brenner, 2006) or on bilateral distances between companies (Marcon \& Puech, 2003; Duranton \& Overman, 2005). However, since our aim is not to define the geographical scope of the cluster but rather to compare territories whose boundaries have already been determined, the LQ method is considered to be appropriate for our analysis.

Regarding the geographical division, we thought about considering the local labor markets as the location variable measure, as it has been considered in previous works to locate a regional tourism clusters in Valencia (Miret-Pastor et al., 2010) or at a national level in Italy (Lazzeretti \& Capone, 2006; Capone \& Boix, 2008). However, the resulting maps we identified were too much fragmented.

Finally, we decided to use geographic areas officially recognized, which makes the analysis more simple, understandable and useful, especially for agents responsible for tourism planning, since these entities have competencies in tourist promotion strategies.

In previous research on the Spanish tourism clusters, the town has been considered as geographical reference (Auriol, 2008; Merinero, 2008); however, there is a consensus about the expansion of the economies of location, going beyond the municipal area and expanding wider (Alonso et al., 2003). We could have chosen the region as the geographical reference (Segarra et al., 2011), the provincial area (Alvarez \& Gonzalez, 2008) or even regions (Alvarez \& Gonzalez, 2006). We have finally decided to analyze the data using the provincial division, being aware that this geographical division carries a high degree of internal heterogeneity, but also the advantage of being officially recognized territories whose institutions (the provincial or regional governments in uniprovincial regions) play an important role in the design and implementation of tourism policies. It is precisely the institutional role, along with the provincial associations, which is one of the reasons for this choice, explaining that many of the most popular Spanish tourist brands worldwide totally fit (or largely) with provincial boundaries (Table 1).

Since there is no formal definition of the tourism sector at a statistical level, we identified some of the sectors or subsectors represented in the NACE code.

The term tourism industry is still used regarding the segments belonging to tourism including sectors directly related to tourism and non-hotel business, in line with the work of Leidner (2004). NACE 
sectors that identify the whole tourism industry can be considered Travel agencies and tour operators 633, hotels and other accommodation 551-552 and restaurants, bars, canteens, catering 553-555.

Upon applying the LQ to the 49 Spanish provinces, the highest rates were found in the provinces represented in Table 2.

The LQ forces us to seek an arbitrary cut-off point from which to consider the concentration of employees to be high, meaning that there is a possibility of a cluster. In this study, a cut-off value of 1.25 was set in line with the work of Miller et al. (2001) and Lazzeretti and Capone (2006).

Table 1. Correspondence between tourism brands and Spanish provinces

\begin{tabular}{ll}
\hline Tourism Brand & \multicolumn{1}{c}{ Province } \\
\hline Costa del Sol & Málaga \\
Costa Blanca & Alicante \\
Costa Brava & Girona \\
Costa del Azahar & Castellón \\
Costa Dorada & Tarragona \\
Costa Tropical & Granada \\
Costa Cálida & Murcia \\
Balearic Islands & Mallorca \\
Canary Islands & Santa Cruz de Tenerife \\
& Las Palmas de Gran Canaria \\
\hline
\end{tabular}

Source: Compiled by authors based on reports from Exceltur.org.

The six provinces listed in the table were the only ones meeting the requirement of having an LQ greater than 1.25 and which could be identified with the six main Spanish tourism clusters. Since the Canary Island provinces correspond to the Canary Islands tourism cluster, the results were grouped into five clusters which were equivalent to five tourist destinations (Figure 1).

By using the province as a field of reference, we found five major tourism clusters, easily recognizable worldwide and we quickly identified not only the same model of tourism (3S), but also a model of tourism cluster "mature".

The traditional Spanish touristic model of sun, sea and sand has changed, and actually, we can find large classical localized clusters coexisting with other tourist beach destinations and a thriving urban tourism, nature, rural or cultural brands.

In 2009, these five clusters accounted for $52 \%$ of all bookings in Spanish territory (HOS, 2010). However, in 1999, these destinations accounted for $60 \%$ of all bookings. Noteworthy is that, in a decade, these traditional sun, sea and sand destinations have lost bookings not only in relative but also absolute terms. According to the Hotel Occupancy Survey, from 1999 to 2009, there were 8000 less bookings in 
all five destinations, ${ }^{1} 1$ while bookings increased by over 20,000 in all of Spain in the same period (Figure 2).

Table 2. Provinces with the highest specialization values

\begin{tabular}{lr}
\hline Province & LQ \\
\hline Las Palmas de Gran Canaria & 2.37 \\
Balearic Islands & 2.49 \\
Girona & 1.32 \\
Santa Cruz de Tenerife & 2.18 \\
Málaga & 1.72 \\
Alicante & 1.29 \\
\hline
\end{tabular}

Source: Compiled by authors with data from the Spanish Census (2001).

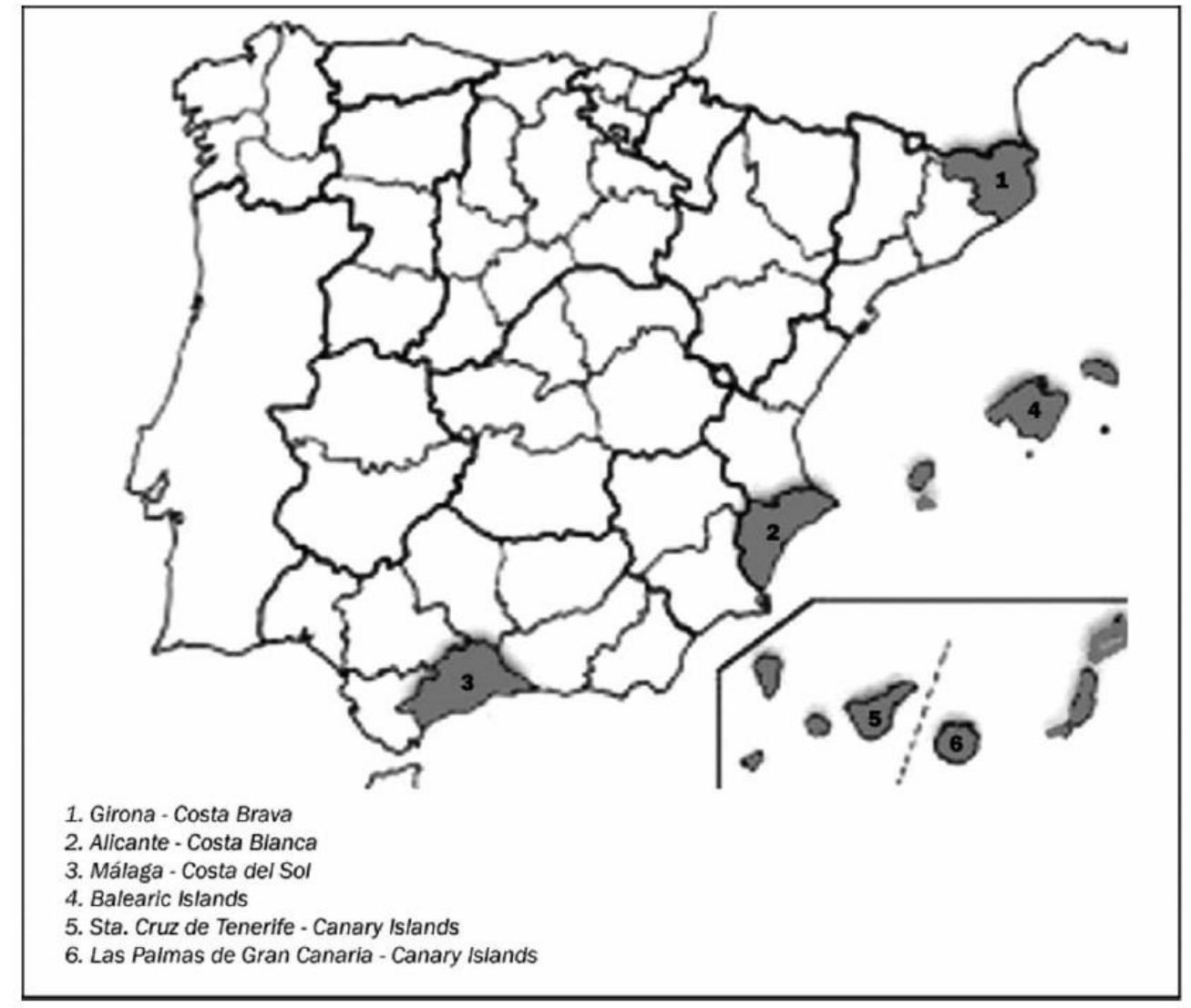

Figure 1. Spanish tourism clusters.

Source: Compiled by authors.

In view of these data, a question arises as to whether the location of hotels in mature tourism clusters continues to offer a competitive advantage. The changes in the number of bookings might indicate that it is more profitable for hotels to be located outside the tourism clusters, but they might

${ }^{1}$ This decrease was mostly caused by the decline in tourists in the Balearic Islands. 
also imply that other tourist destinations (in other provinces), and even alternative tourism models (rural tourism, city, etc.) have emerged or been consolidated. Consequently, it is necessary to analyze whether the economies of location which once led to the emergence and consolidation of the major Spanish tourist destinations continue to be valid today. For this purpose, we proposed studying whether the location within clusters affects the economic and financial rations of hotel and catering companies based on the following research hypothesis:

H1: Hotels located inside tourism clusters perform better economically than those located outside the clusters.

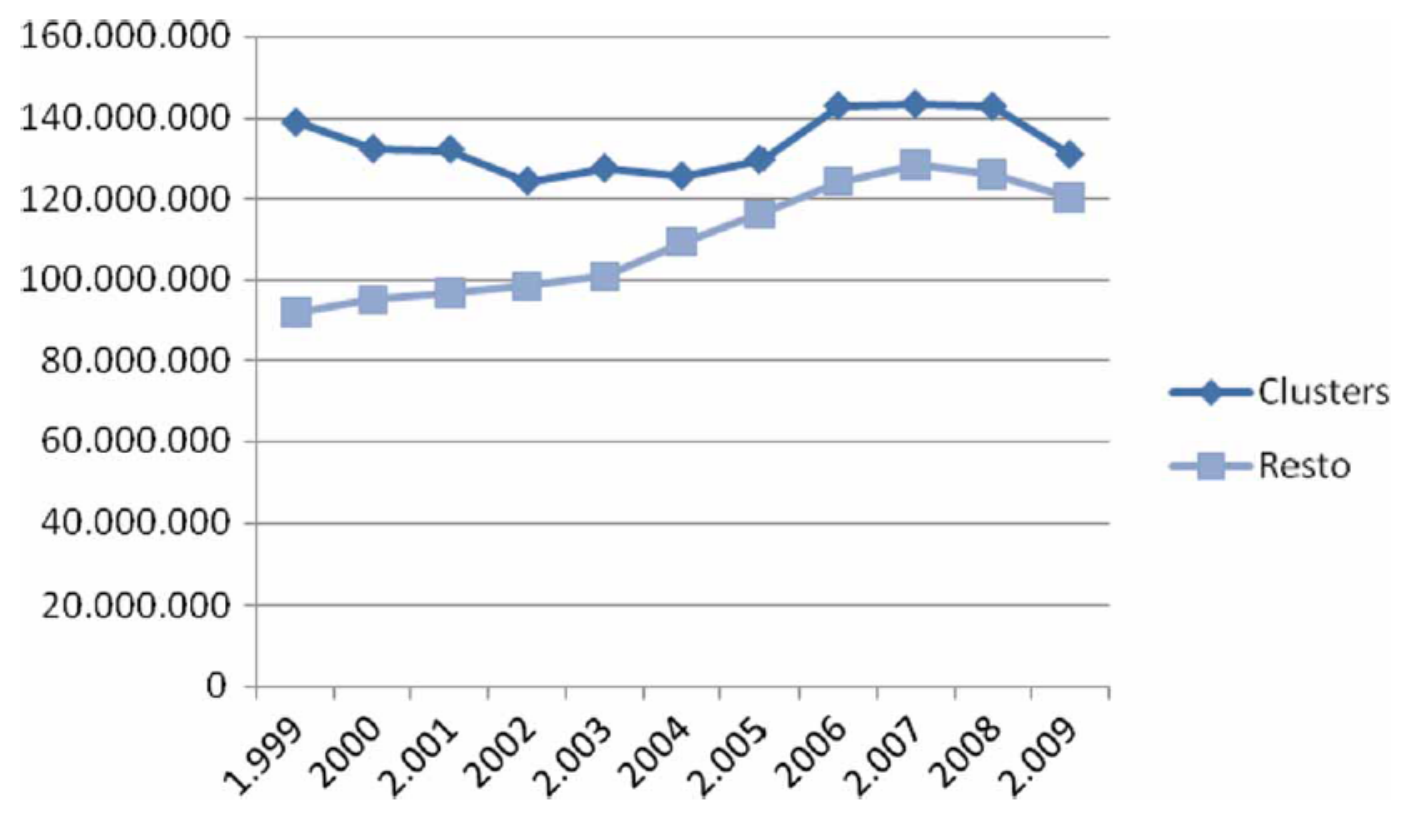

Figure 2. Bookings evolution from 1999 to 2009.

Source: Compiled by authors based on data from the Hotel Occupancy Survey (2009).

\section{Validity of Agglomeration Economies in Spanish Tourism Clusters}

\section{Data and Methodology}

To validate this hypothesis, a sample was analyzed comprising a total of 7699 Spanish hotels, which are shown in Table 3.

From the total of 7699 hotels identified at the SABI database (2008 version), 5368 hotels were considered not located in a tourist cluster according to previous analysis (see Section 3) and 2331 were 
considered to belong to a cluster. Sixty-eight hotels were discarded due to the lack of some data necessary for the analysis.

Table 3. Classification of hotels studied

\begin{tabular}{lc}
\hline & Hotels in the cluster \\
\hline Canary Islands & 558 \\
Balearic Islands & 856 \\
Girona & 386 \\
Málaga & 260 \\
Alicante & 271 \\
Hotels analysed within clusters & 2331 \\
Hotels analysed outside of clusters & 5368 \\
Total number of hotels analysed & 7699 \\
\hline
\end{tabular}

Source: SABI (2008) and compiled by authors.

In the second part of the study, analysis of variance (ANOVA) was performed using the SPSS.17.0 program. ANOVA is a statistical technique in which the variance is broken down into independent parts with different explanatory variables. This analysis is used to compare whether the values of a set of numerical data are significantly different from the values of one or more other sets of data (Ching-Hui et al., 2010). In our case, the selected variables were used to compare hotels located in tourism clusters identified in the first part of the study and the rest of Spanish hotels (those which do not benefit from belonging to the previously identified clusters). The procedure for comparing these values was based on the overall variance observed in the groups of numerical data to be compared.

The ANOVA analysis indicates whether the null hypothesis indicating the equality of the means for a given level of significance should be accepted or rejected. In other words, an attempt was made to verify whether the means of the variables analyzed were significantly different between the groups analyzed.

The variables studied for each of the hotels are "Income per employee", "Sales per employee" and "Size" (measured by the number of employees). EBITDA (earning before interest, taxes, depreciation and amortization per employee) was chosen as the variable to be used to measure "profitability", since it is considered to be one of the most reliable and popular indicators for measuring and comparing financial profit. We have considered all the variables per employee in order to eliminate any correlation existing among size and economic results.

Results

The empirical results obtained are shown in Table 4. 
In the case of all the variables studied (income/per employee, sales/per employee, size, EBITDA/per employee), the means for the hotels located inside the cluster were significantly higher than for the hotels outside the cluster. Empirical evidence showed significant differences between companies which were located inside tourism clusters and those which were not. Therefore, it can be concluded that the hotels located inside clusters generate higher income, sell more and show more profit, meaning that the hypothesis proposed "Hotels located inside tourism clusters perform better economically than those located outside the clusters" can be validated.

Table 4. Comparison of means (one-way ANOVA) in hotels inside and outside of the tourism clusters identified

\begin{tabular}{|c|c|c|c|c|}
\hline ANOVA & & Mean & $F$ & Sig. \\
\hline \multirow[t]{3}{*}{ Net incomes per employee (thousand $€$ ) } & Located (2349) & 120.346 & \multirow[t]{3}{*}{5.640} & \multirow[t]{3}{*}{$0.018^{*}$} \\
\hline & Not located (5368) & 84.66 & & \\
\hline & Total & 95.52 & & \\
\hline \multirow[t]{3}{*}{ Sales per employee (thousand $€$ ) } & Located & 112.60 & \multirow[t]{3}{*}{4.766} & \multirow[t]{3}{*}{$0.029^{*}$} \\
\hline & Not located & 80.15 & & \\
\hline & Total & 90.03 & & \\
\hline \multirow[t]{3}{*}{ Size (no. empl.) } & Located & 30.92 & \multirow[t]{3}{*}{142.315} & \multirow[t]{3}{*}{$0.000^{* *}$} \\
\hline & Not located & 17.09 & & \\
\hline & Total & 21.30 & & \\
\hline \multirow[t]{3}{*}{ EBITDA per employee (thousand $€$ ) } & Located & 18.19 & \multirow[t]{3}{*}{4.219} & \multirow[t]{3}{*}{$0.040^{*}$} \\
\hline & Not located & 13.17 & & \\
\hline & Total & 14.70 & & \\
\hline
\end{tabular}

Note: Full sample with values per employee.

After obtaining these results and validating the hypothesis posed, it was necessary to determine whether the results could be assumed in the case of all the clusters identified, and for this purpose, individual analyses were performed in order to avoid possible distortions. The empirical results are shown in Tables 5-9.

Again, significant differences were found for most of the variables studied. In the hotels located in the tourism clusters of the Canary Islands, Balearic Islands and Málaga (Tables 5-7), clear differences were evidenced, such as higher operating income and net sales, as well as higher profit measured by means of EBITDA per employee. In other words, these hotels are more profitable than the other domestic hotels not located inside a tourism cluster. Hotels in Alicante are more profitable in terms of Net incomes/per employee and sales/per employee but results are not transferred to EBITDA/per employee. The same results were not evidenced in the case of the clusters of Gerona (Table 9). As for the Hotels in Girona, all the indicators studied show figures which are lower than those shown for hotels located outside the clusters. In the case of Girona, it should be noted that unlike in the other provinces 
studied, tourism is very heterogeneous since together with the sun, sea and sand tourism of the Costa Brava there is a significant rural, cultural and snow tourism, etc.

In any case, these results prove that it is important to be cautious when considering and generalizing the findings of our study. Although this study analyses Spanish tourism clusters in general, and although it is evident that there are similarities between all of them, each of these clusters should be considered as a different destination with its own features and trends.

\section{Conclusions}

The statistical analyses performed in this study enabled us to identify six Spanish provinces with specialization levels that can be defined as tourism clusters and which correspond to the five classic Spanish sun, sea and sand tourism destinations (la Costa Blanca, la Costa del Sol, la Costa Brava, the Balearic Islands and the Canary Islands).

These five destinations now account more over $50 \%$ of hotel bookings in Spanish territory. However, in recent years, both in absolute and relative terms, these figures have decreased.

Furthermore, combined with this empirical evidence is the consideration by different experts that these destinations are in a phase of stagnation or decline.

Table 5. Comparison of means (one-way ANOVA) in hotels inside and outside of the Canary Islands tourism cluster

\begin{tabular}{llccc}
\hline ANOVA & & Mean & $F$ & Sig. \\
\hline Net incomes per employee (thousand $€$ ) & Located (560) & 144.851 & 15.135 & $0.000^{* *}$ \\
& Not located (5368) & 84.66 & & \\
& Total & 102.98 & & \\
Sales per employee (thousand $€$ ) & Located & 134.61 & 14.092 & $0.000^{* *}$ \\
& Not located & 80.15 & & \\
Size (no. empl.) & Total & 96.72 & & \\
& Located & 49.36 & 251.428 & $0.000^{* *}$ \\
& Not located & 17.09 & & \\
EBITDA per employee (thousand $€$ ) & Total & 26.91 & & \multirow{2}{*}{ Located } \\
& Not located & 21.77 & 5.330 & $0.021^{*}$ \\
& Total & 13.17 & & \\
\hline
\end{tabular}

Therefore, it is necessary to analyze the validity of economies of location which once made possible the birth and success of these destinations, success which is now at stake. In other words, the hypothesis that "hotels located inside tourism clusters perform better economically than those located outside the clusters" can be posed. 
By means of ANOVA, four economic indicators were compared, and it was concluded that for all the variables studied, the means for hotels located inside the clusters were significantly higher than for hotels located outside the clusters, which allowed us to validate the hypothesis posed. It has to be pointed out that all the variables have been studied referred to the number of employees, so we can compare them without considering the importance that the size of the hotel could have on the economic performance.

Table 6. Comparison of means (one-way ANOVA) in hotels inside and outside of the Balearic Islands tourism cluster

\begin{tabular}{|c|c|c|c|c|}
\hline ANOVA & & Mean & $F$ & Sig. \\
\hline \multirow[t]{3}{*}{ Net incomes per employee (thousand $€$ ) } & Located (862) & 120.215 & \multirow[t]{3}{*}{5.920} & \multirow[t]{3}{*}{$0.015^{*}$} \\
\hline & Not located (5368) & 84.66 & & \\
\hline & Total & 95.48 & & \\
\hline \multirow[t]{3}{*}{ Sales per employee (thousand $€$ ) } & Located & 111.04 & \multirow[t]{3}{*}{5.329} & \multirow[t]{3}{*}{$0.021^{*}$} \\
\hline & Not located & 80.15 & & \\
\hline & Total & 89.55 & & \\
\hline \multirow[t]{3}{*}{ Size (no. empl.) } & Located & 30.25 & \multirow[t]{3}{*}{74.291} & \multirow[t]{3}{*}{$0.000^{* *}$} \\
\hline & Not located & 17.09 & & \\
\hline & Total & 21.10 & & \\
\hline \multirow[t]{3}{*}{ EBITDA per employee (thousand $€$ ) } & Located & 20.05 & \multirow[t]{3}{*}{4.548} & \multirow[t]{3}{*}{$0.033^{*}$} \\
\hline & Not located & 13.17 & & \\
\hline & Total & 15.26 & & \\
\hline
\end{tabular}

Table 7. Comparison of means (one-way ANOVA) in hotels inside and outside of the Málaga tourism cluster

\begin{tabular}{llccc}
\hline ANOVA & & Mean & $F$ & Sig. \\
\hline Net incomes per employee (thousand $€$ ) & Located (264) & 133.846 & 6.827 & $0.009^{* *}$ \\
& Not located (5368) & 84.66 & & \\
& Total & 99.63 & & \\
Sales per employee (thousand $€$ ) & Located & 129.20 & 6.875 & $0.009^{* *}$ \\
& Not located & 80.15 & & \\
Size (no. empl.) & Total & 95.08 & & \multirow{2}{*}{$0.009^{* *}$} \\
& Located & 23.45 & 6.929 & \\
EBITDA per employee (thousand $€$ ) & Not located & 17.09 & & \\
& Total & 19.03 & & \\
& Located & 17.81 & 3.211 & 0.073 \\
& Not located & 13.17 & & \\
\hline
\end{tabular}

A subsequent individual analysis continued offering similar evidence for the majority of clusters analyzed, although it was necessary to make some significant qualifications. 
Table 8. Comparison of means (one-way ANOVA) in hotels inside and outside of the Alicante tourism cluster

\begin{tabular}{llccc}
\hline ANOVA & & Mean & $F$ & Sig. \\
\hline Net incomes per employee (thousand $€$ ) & Located (272) & 115.524 & 4.985 & $0.026^{*}$ \\
& Not located (5368) & 84.66 & & \\
& Total & 94.05 & & \\
Sales per employee (thousand $€$ ) & Located & 107.40 & 4.302 & $0.038^{*}$ \\
& Not located & 80.15 & & \\
Size (no. empl.) & Total & 88.44 & & \multirow{2}{*}{$0.005^{* *}$} \\
& Located & 23.68 & 7.886 & \\
& Not located & 17.09 & & \\
EBITDA per employee (thousand $€$ ) & Total & 19.10 & & \\
& Located & 14.53 & 0.821 & 0.365 \\
& Not located & 13.17 & & \\
\hline
\end{tabular}

Table 9. Comparison of means (one-way ANOVA) in hotels inside and outside of the Girona tourism cluster

\begin{tabular}{lllll}
\hline ANOVA & & Mean & $F$ & Sig. \\
\hline Net incomes per employee (thousand $€$ ) & Located (391) & 79.774 & 0.101 & 0.751 \\
& Not located (5368) & 84.66 & & \\
& Total & 83.17 & & \\
Sales per employee (thousand $€$ ) & Located & 76.93 & 0.045 & 0.831 \\
& Not located & 80.15 & & \\
Size (no. empl.) & Total & 79.17 & & \multirow{2}{*}{0.608} \\
& Located & 16.10 & 0.263 & \\
EBITDA per employee (thousand $€$ ) & Not located & 17.09 & & \\
& Total & 16.79 & & \\
& Located & 11.80 & 0.024 & 0.878 \\
& Not located & 13.17 & & \\
\hline
\end{tabular}

The conclusion of this quantitative analysis was that despite the stagnation in the number of tourists and the fact that these destinations could be considered to be mature, economies of location are still valid both overall and for each of the main Spanish tourism clusters.

In any case, the trend towards a change in the global tourism model requires the adaptation of these destinations to a rapidly changing and competitive environment. As reflected in many studies, these destinations have transformed and renewed the tourism possibilities offered, and they have done so as true tourism clusters "cooperating locally to compete globally".

The existence of tourism clusters has proved to be a tool which is able to positively influence economic performance, and therefore, the competitiveness of the companies located inside these clusters. If future tourism policies are meant to be as efficient and effective as possible, the existence of tourism clusters will have to be taken into account, and the understanding and strengthening of these clusters will need to be advanced. 
The analysis of these mass destinations as tourism clusters opens the door to future studies which identify and analyze the economies of locations by which they are substantiated. This paper has used a very broad concept of economies of location; we should also study the importance of urbanization economies, the different resources and demand externalities, as well as the analysis of geographical and sector areas into which they expand, in addition to the relationships existing inside those clusters.

\section{References}

Agarwal, S. (2002) Restructuring seaside tourism: The resort lifecycle, Annals of Tourism Research, 29(1), pp. 25-55.

Aguiló, E., Alegre, J. \& Sard, M. (2005) The persistence of the sun and sand tourism model, Tourism Management, 26(2), pp. 219-231.

Alegre, J. \& Caldera, M. (2006) Repeat visitation in mature sun and sand holiday destinations, Journal of Travel Research, 44(3), pp. 288-297.

Alegre, J. \& Garau, J. (2011) The factor structure of tourist satisfaction at sun and sand destinations, Journal of Travel Research, 50(1), pp. 78-86.

Alonso, O., Chamorro, J. M. \& González, X. (2003) Spillovers geográficos y sectoriales de la industria, Revista de Economía Aplicada, 32(XI), pp. 77-95.

Alvarez, J. A. \& Gonzalez, O. (2006) L'apprentissage, l'innovation et la compétitivite dans les clusters touristiques: une etude compare entre l'Espagne et l'Italie, Revue d'Economie regionale et urbaine, 4, pp. 551-574.

Alvarez, J. A. \& Gonzalez, O. (2008) La competitividad de los clusteres turísticos españoles, Annals of Tourism Research, 10(2), pp. 439-457.

Aurioles, J., Fernandez, M. C. \& Manzanera, E. (2008) El distrito turístico, Mediterráneo económico, 13(6), pp. 299-326.

Avraham, E. \& Ketter, E. (2008) Media Strategies for Marketing Places in Crisis: Improving the Image of Cities, Countries and Tourist Destinations (Oxford: Butterworth-Heinemann).

Bernini, C. (2009) Convention industry and destination clusters: Evidence from Italy, Tourism Management, 30(6), pp. 878-889.

Blasco, D., Guia, J., Prats, L. \& Sáez, M. (2009) Clusters turisticos en Cataluña. Una propuesta de organización turística del territorio, Revista de economía, sociedad, turismo y medio ambiente: RESTMA (8-9), pp. 77-97. 
Brenner, T. (2006) Identification of local industrial clusters in Germany, Regional Studies, 40(9), pp. 114.

Butler, R. (1980) The concept of a tourist area cycle evolution: Implications for management of resources, The Canadian Geographer, 24(1), pp. 5-112.

Canielli, G. \& De Liso, N. (2004) Can a Marshallian industrial district be innovative? The case of Italy, in: The Evolution of Industrial Districts: Changing Governance, Innovation and Internationalisation of Local Capitalism in Italy (Heidelberg: Phisica-Verlag).

Canina, L., Enz, K. \& Harrison, J. (2005) Agglomeration effects and strategic orientations: Evidence from the US lodging industry, Academy of Management Journal, 48(4), pp. 565-581.

Capone, F. \& Boix, R. (2008) Sources of growth and competitiveness of local tourist production systems: An application to Italy (1991-2001), The Annals of Regional Science, 42(1), pp. 209-224.

Ching-Hui, Ch., Nabendu, P., Wooi Khai, L. \& Jyh-Jiuan, L. (2010) Comparing several population means: A parametric bootstrap method, and its comparison with usual ANOVA F test as well as ANOM, Computational Statistics, 25(1), pp. 71-95.

Chun, W. \& Kalnins, A. (2001) Agglomeration effects and performance: A test of the Texas Lodging Industry, Strategic Management Journal, 22(10), pp. 969-988.

Claver-Corte's, E., Molina-Azorín, J. F. \& Pereira-Moliner, J. (2007) Competitiveness in mass tourism, Annals of Tourism Research, 34(3), pp. 727-745.

Cook, G. A. S., Pandit, N. R., Beaverstock, J. V., Taylor, P. J. \& Pain, K. (2007) The role of location in knowledge creation and diffusion: Evidence of centripetal and centrifugal forces in the city of London financial services agglomeration, Environment and Planning, 39(6), pp. 1325-1345.

Duranton, G. \& Overman, H. G. (2005) Testing for location using micro-geographic data, Review of Economic Studies, 72(25), pp. 1077-1106.

Ellison, G. \& Glaeser, E. (1997) Geographic concentration in U.S. manufacturing industries: A Dartboard approach, Journal of Political Economy, 105(5), pp. 889-927.

Erkus-Öztürk, H. (2009) The role of cluster types and firm size in designing the level of network relations: The experience of the Antalya tourism region, Tourism Management, 30(4), pp. 589-597.

Esteban Talaya, A., Mondéjar Jiménez, J. A. \& Cordente Rodríguez, M. (2009) Algunos conceptos de marketing y medio ambiente: Una propuesta de revisión, Revista de economía, sociedad, turismo y medio ambiente: RESTMA (8-9), pp. 47-75.

Fabiani, S. (2000) L'efficienza delle imprese nei distretti industriali italiani in Modelli di Sviluppo Locale: Produzioni, Mercati e Finanza, Banca d'Italia Eds. 
Farsari, Y., Butler, R. \& Prastacos, P. (2007) Sustainable tourism policy for Mediterranean destinations: Issues and interrelationships, International Journal of Tourism Policy, 1(1), pp. 58-70.

Fayos, E. (1996) Tourism policy: A midsummer night's dream? Tourism Management, 17(6), pp. 405412.

Ferreira, J. M. \& Estevao, C. M. S. (2009) Competitividade regional de um cluster de turismo: uma proposta de modelo conceptual, Encontros Científicos, 5(2), pp. 37-51.

Flowers, J. \& Easterling, K. (2006) Growing South Carolina's tourism cluster, Business and Economic Review, 52(3), pp. 15-20.

Hall, C. M. (2005) Rural wine and food tourism cluster network development, in: D. Hall I Kirkpatrick \& M. Mitchell (Eds) Rural Tourism and Sustainable Business, pp. 149-164 (Clevedon: Channel View Publications).

Hayden, C. (2009) Media strategies for marketing places in crisis: Improving the image of cities, countries and tourist destinations-by Eli Avraham and Eran Ketter, Journal of Communication, 59(4), pp. 30-33.

Henderson, J. V., Lee, T. \& Lee, Y. J. (2001) Scale externalities in Korea, Journal of Urban Economics, 49(3), pp. 479-504.

Hernández, F. \& Soler, V. (2003) Cuantificación del efecto distrito a través de medidas no radiales de eficiencia técnica, Investigaciones Regionales, (3), pp. 25-40.

Hjalager, A. M. (2000) Tourism destinations and the concept of industrial districts, Tourism and Hospitality Research, 2(3), pp. 199-213.

Hos. (2010) Hotel occupance survey. Available at http://www.ine.es (accessed February 2011).

Inkpen, A. C. \& Tsang, E. W. K. (2005) Social capital, networks and Knowledge transfer, Academy of Management Review, 30(1), pp. 146-165.

Ioannides, D. \& Debbage, K. (1997) Neo-Fordism and flexible specialization in the travel industry. Dissecting the polyglot, in: D. Ioannides \& K. Debbage (Eds) Economic Geography of the Tourist, pp. 99-122 (London: Routledge).

Jackson, J. \& Murphy, P. (2002) Tourism destinations as clusters: Analytical experience from the New World, Tourism and Hospitality Research, 4(1), pp. 36-52.

Jackson, J. \& Murphy, P. (2006) Clusters in regional tourism destinations: An Australian case, Annals of Tourism Research, 33(4), pp. 1018-1035.

Jacobs, J. (1969) The Economy of Cities (New York: Vintage). 
Knowles, T. \& Curtis, S. (1999) The market viability of European mass tourist destinations: A poststagnation life-cycle analysis, International Journal of Tourism Research, 1(2), pp. 87-96.

Kumral, N. \& Onder, O. (2009) Tourism regional development and public policy: Introduction to the special issue, European Planning Studies, 17(10), pp. 1441-1443.

Lazzeretti, L. \& Capone, F. (2006) Identification and analysis of tourist local systems: An application to Italy (1996-2001), in: L. Lazzeretti \& C. Petrillo (Eds) Tourism Local Systems and Networking, pp. 25-42 (Amsterdam: Elsevier).

Leidner, R. (2004) The European Tourism Industry: A Multi-sector with Dynamic Markets (Luxembourg: European Commission).

Marcon, E. \& Puech, F. (2003) Evaluating the geographic concentration of industries using distancebased methods, Journal of Economic Geography, 3(4), pp. 409-428.

Marrero, J. R. \& Santana, M. A. (2008) Competitividad y calidad en los destinos turísticos de sol y playa: el caso de las Islas Canarias, Cuadernos de turismo, (22), pp. 123-143.

Mazanec, J., Wöber, K. \& Zins, A. (2007) Tourism destination competitiveness: From definition to explanation? Journal of Travel Research, 46(1), pp. 86-95.

Melitz, M. J. (2003) The impact of trade on intra-industry reallocations and aggregate industry productivity, Econometrica, 71(6), pp. 1695-1725.

Merinero, R. (2008) Micro-cluster turísticos: el papel del capital social en el desarrollo económico local, Revista de Estudios Empresariales, (2), pp. 67-92.

Michael, E. J. (2003) Tourism micro-clusters, Tourism Economics, 9(2), pp. 133-145.

Miller, P., Botham, R., Gibson, H., Martin, R. \& Moore, B. (2001) Business Clusters in the UK-A First Assessment, Main Report. Londres: Department of Trade and Industry.

Miret-Pastor, L. \& Segarra-Oña, M. (2010) El papel de los Mercados Locales Laborales en la aglomeración industrial y cómo las economías externas explican la importancia del territorio, Tec Empresarial, 4(1), pp. 23-31.

Miret-Pastor, L., Segarra-Oña, M. \& Hervás-Oliver, J. L. (2010) Nuevas Medidas de Concentración Espacial Aplicadas al Sector Turístico: El Papel de las Externalidades en el Turismo de la Comunidad Valenciana, in: G. Ferrari, J. M. Montero-Lorenzo, J. Mondéjar-Jiménez \& M. VargasVargas (Eds) Investigaciones, métodos y análisis del turismo (Septem ediciones), Oviedo, Spain.

Miret-Pastor, L., Segarra-Oña, M. \& Peiró-Signes, A. (2011) Identificación de sectores de servicios y de alta tecnología en la Comunidad Valenciana: "Un nuevo cluster mapping", Revista de Estudios Regionales, Forthcoming. http://www.revistaestudiosregionales.com/articulos_pendientes.php) 
Moutinho, L. (2000) Trends in tourism, in: L. Moutinho (Ed.) Strategic Management in Tourism, pp. 3-16 (Wallingford: CAB International).

Nordin, S. (2003) Tourism Clustering and Innovation-Paths to Economic Growth and Development (Oestersund, Sweden: European Tourism Research Institute, Mid-Sweden University).

Novelli, M., Schmitz, B. \& Spencer, T. (2006) Networks, clusters and innovation in tourism: A UK experience, Tourism Management, 27(6), pp. 1141-1152.

O'Donoghue, D. \& Gleave, B. (2004) A note on methods for measuring industrial agglomeration, Regional Studies, 38(4), pp. 419-427.

Pandit, N. R., Cook, G. A. S., Beaverstock, J. V. \& Ghauri, P. (2008) An empirical study of service sector clustering an multinational enterprises, Journal of Services Research, 8(special issue), pp. 23-39.

Papatheodorou, A., Rosello, J. \& Xiao, H. (2010) Global economic crisis and tourism: Consequences and perspectives, Journal of Travel Research, 49(1), pp. 39-45.

Pearce, D. G. (1995) Tourism Today: A Geographical Analysis (Harlow: Longman).

Polo, C. \& Valle, E. (2008) An assessment of the impact of tourism in the Balearic Islands, Tourism Economics, 14(3), pp. 615-630.

Poon, A. (1993) Tourism, Technology and Competitive Strategies (Oxon: CAB International).

Porter, M. E. (1998) Clusters and the new economics of competition, Harvard Business Review, November- December, pp. 77-90.

Prats, L., Guia, J. \& Molina, F. X. (2008) How tourism destinations evolve: The notion of tourism local innovation system, Tourism and Hospitality Research, 8(3), pp. 178-191.

Presenza, A. \& Cipollina, M. (2010) Analysing tourism stakeholders networks, Tourism Review, 65(4), pp. 17-30.

Puig-Blanco, F., Berbel-Pineda, J. M. \& Debón-Aucejo, A. (2008) El desigual efecto de la globalización entre las empresas textiles españolas, Investigaciones Regionales, (12), pp. 59-78.

Pulina, M. \& Biagi, B. (2010) The evolution of tourism demand and supply: A regional policy study, International Journal of Tourism Policy, 3(3), pp. 237-256.

Richards, G. \& Wilson, J. (2006) Developing creativity in tourist experiences: A solution to the serial reproduction of culture? Tourism Management, 27, pp. 1209-1220.

Saxena, G. (2005) Relationships, networks and the learning regions: Case evidence from the Peak District National Park, Tourism Management, 26(2), pp. 277-289.

Segarra-Oña, M. \& De Miguel-Molina, B. (2009) Evaluación de la concentración industrial sinérgica. Propuesta metodológica y aplicación a un sector industrial, Tec Empresarial, 3(1-2), pp. 65-72. 
Segarra-Oña, M., Miret-Pastor, L. \& Peiró-Signes, A. (2011) Identificación y análisis de clústers turísticos en la Comunidad Valenciana: "influye la localización en los resultados empresariales". Revista de economía, sociedad, turismo y medio ambiente, RESTMA, 13, pp. 9-28.

Segreto, L., Manero, C. \& Pohl, M. (2009) Europe at the Sea Side. Economic History of the Mass Tourism in the Mediterranean (New York, NY: Berhahn Books).

Sharma, A., Sneed, J. \& Ravichandran, S. (2007) Spatial analysis of small hotel activity in Tanzania, International Journal of Contemporary Hospitality Management, 19(7), pp. 589-599.

Sherrer, P., Alonso, A. \& Sheridan, L. (2009) Expanding the destination image: Wine tourism in the Canary Islands, International Journal of Tourism Research, 11(5), pp. 451-463.

Signorini, L. F. (1994) The price of Prato, or measuring the industrial district effect, Papers in Regional Science, 73(4), pp. 369-392.

Soler, V. (2006) Nuevas técnicas para la medición del efecto distrito en las aglomeraciones industriales, Economía Industrial, (359), pp. 81-88.

Tinsley and Lynch (2001) Small tourism business networks and destination development, International Journal of Hospitality Management, 20(4), pp. 367-378.

Unwto. (2010) World tourism barometer. Available at: http://www.unwto.org/facts/eng/barometer.htm (accessed February 2011).

Valenzuela, M. (1991) Spain: The phenomenon of mass tourism, in Tourism and Economic Development, in: A. M. Williams \& G. Shaw (Eds) Western European Experiences, 2nd ed., pp. 40-60 (Exeter, UK: Exeter University).

Van den Berg, L., Braum, E. \& Van Winden, W. (2001) Growth Cluster in European Metropolitan Cities (Aldershot: AshGate).

Weber, A. (1909) Theory of the Location of Industries (Chicago, IL: University of Chicago Press).

Weidenfeld, A., Butler, R. \& Williams, A. (2010) Clustering and compatibility between tourism attractions, International Journal of Tourism Research, 12(1), pp. 1-16. 